\title{
Liberal democracy and the genetic supermarket: Autonomy and freedom in Jürgen Moltmann's political theology and biotechnology ${ }^{1}$
}

\author{
Kotzé, Manitza \\ University of the Western Cape \\ manitza@gmail.com
}

\begin{abstract}
In this article, the concept of "liberal democracy" and its implications for biotechnology such as human genetic engineering will be examined. Liberal democracy is characterised by a number of features, some of which has extensive repercussions on biotechnology, especially concepts such as the equal protection of human rights, civil rights, civil liberties, political freedom for all people and autonomy and libertarianism. Advocates of human genetic engineering for purposes other than the healing of genetically transmitted diseases often appeal to these features in the quest for its legalisation. I will examine whether the attributes of liberal democracy would indeed justify the use of this type of biotechnology and if yes, what a possible theological response would be, drawing on the political theology of Jürgen Moltmann.
\end{abstract}

Keywords

Autonomy, Freedom, Genetic engineering, Liberal democracy, Moltmann

\section{Introduction}

Biotechnology and aspects of liberal democracy have been closely linked together from the very beginning, with Robert Nozick, the father of libertarianism coining the phrase "the genetic supermarket", which I use in the title of this article, already in 1974 in Anarchy, State and Utopia. As Colin Gavaghan indicates, the great virtue of the genetic supermarket,

1 Note: Paper delivered at the annual conference of the Theological Society of South Africa, with the theme Citizens or Subjects? Theological and ethical reflection on participatory democracy in South Africa, hosted in Potchefstroom, 18-20 June 2014. 
for Nozick, is that it "involves no centralised decision fixing the future of human type(s)" (2007:1). Forty years after Nozick expounded his theory of libertarianism, where justice is identified with the idea of liberty where each person is free to act in whatever way he or she chooses and, as long as they are not harming the liberty of another person, this liberty may not be interfered with (Shaw 2005:34), biotechnology has developed in ways he perhaps never imagined.

Religion and theology cannot be kept out of the public sphere, also when it comes to bioethical discussion on biotechnology, such as human genetic engineering. Richard Neuhaus refers to the impossibility of sustaining what he calls the "religious evacuation of the public square", indicating that when traditional or identifiable religion becomes barred from the public sphere, this does not mean that religion retreats from the public sphere. Rather, the void left by the exclusion of religion will be filled by ersatz religion, "religion bootlegged into public space under other names" (Neuhaus 1984:80, quoted in Lombard 2011:239).

This aspect is especially relevant to the notion of biotechnology, where a phrase such as "playing God", at its very core a religious expression, is often also used in secular discourses without accounting for the way that it is utilised or the intended meaning.

Biotechnological treatments such as genetic engineering (GE), also of human beings, are challenging Christian theological ethics in new ways and requiring responses that keep up with the development of technology. Advocates of the use of GE often appeal to the various features of liberal democracy, with notions of liberty, the freedom and autonomy of parents to make decisions regarding their children, also in terms of their genetic makeup, being demanded. Notions that are central to liberal democracy such as separation of powers, the equal protection of human rights, civil rights, civil liberties, and political freedom for all people, autonomy and libertarianism have obvious repercussions for an ethical response to biotechnology. In this paper, I will examine whether a Christian bioethical response to the notions of autonomy and liberty as challenges raised by human genetic engineering is valuably informed by the political theology of Jürgen Moltmann, a relevant theologian to offer guidance in this regard, as has he offered explicit pronouncements regarding genetic engineering. 
In addition, concepts that this article deals with, such as freedom and autonomy, play an important role in his theology.

\section{Liberal democracy and biotechnology: Autonomy}

For some, as Gavaghan postulates, the concern is with what they view as the inherently hubristic, sacrilegious and dehumanising connotations of a technology that would allow the present generation to choose their successors. Others have more concrete concerns, deriving from the fear that people will be harmed, devalued or treated unjustly (Gavaghan 2007:2). Sondra Wheeler also indicates that reproductive autonomy has attained much of its prevalence in the continuing discussion of abortion and has been "understood as the individual's right to freedom from interference or constraint in the exercise of his or her reproductive capacity, including choices about conception, contraception, and termination of pregnancy" (2003:241). Francis Fukuyama further states:

The most important threat posed by contemporary biotechnology is the possibility that it will alter human nature and thereby move us into a 'post human' stage of history. This is important ... because human nature exists, is a meaningful concept, and has provided a stable continuity to our experience as a species. It is, conjointly with religion, what defines our most basic values. (Fukuyama 2002:7)

Autonomy is also of crucial importance in a liberal democracy and is also closely tied to the notion of liberty. As Russell Blackford point out, one of the aspects where biotechnology such as GE is often critiqued is what is regarded as a threat to autonomy. While there are numerous variations of these points of criticism, the two main notions that are most often suggested is that either the resulting child and/or society's liberal political values will be threatened by the use of GE (2014:51). The gist of the argument used most frequently implies that knowing one's person and personality had not only been shaped by early education and upbringing, but also through genetic intervention, directly undermines one's autonomy. As George Annas puts it, too much control in the hands of parents violated the autonomy of their children (2005:41). 
Jürgen Habermas, who have perhaps crafted the most well known and most elaborate argument in this regard, goes one step further and adds that not only is the autonomy of children born after GE threatened, but also the values of modern liberal societies (Blackford 2014:51). Habermas argues that the irreversible decision to alter the "organic disposition" of another person will restrict "the fundamental symmetry that exists among free and equal persons" in modern societies (2003:14). We will not be able to come to the self-understanding of being what he terms "the undivided authors of our lives" (Habermas 2003:49) or be able to develop a perspective of other people as "persons of equal birth" (Habermas 2003:62). Margaret Somerville relies heavily on Habermas's perspective and summarises the problem at hand by indicating that 'designed children' cannot be equal to the designer and that any genetic intervention in the potentiality of a human being is a form of present tyranny over the future (2007:214-215). Michael Sandel further postulates that in order to think of ourselves as free, we have to be able to understand our origin as having a beginning that is beyond the disposal of another human being (2007:81-83).

On the other side of the argument, as Blackford indicates, however, this is not a self-evident claim and one for which Sandel does not offer empirical support. While all of us undoubtedly would fear falling prey to someone (or something) that would be able to reshape our most primary and deep-seated desires, the reason is that future interferences would alter and destroy our present personalities and hopes. Past actions cannot be viewed in the same way, even if our present have been shaped by them, because most parental action form the attributes, beliefs and capacities of a developing child (2014:60-61). He also further indicates that it would be misleading to claim that any of us are primarily responsible for our own desires and characteristics and cites CAJ Coady, who indicates that no person can "regard themselves as the sole authors of their own life history, there is too much contingency and inevitable dependence on others for that to be plausible" (Coady 2009:174, quoted in Blackford 2014:66).

Blackford uses the hypothetical example of Arnold, who at the age of 19 learns that his robust build is not only because of the good nutrition and opportunities for exercise his parents provided as he was growing up, but also genetic tweaking for the potential to develop strong muscles. Blackford asks why the genetic, as well as environmental interventions made by 
Arnold's parents, should make him feel burdened? He indicates that there is no comprehensive control and that Arnold is by no means a puppet; his parents leave wide open "what worldview he might come to accept, what creative and other pleasures he might take up, what attitudes he might bring to such conflicting priorities as work and family, and what temperament he might have" (2014:62). For this reason, Nick Bostrom argues that "being healthy, smarter, having a wide range of talents, or possessing greater powers of self-control are blessings that tend to open more life paths than they block" (2005:212). For Blackford, there is an inherent inequality between parents and children, because the very existence of children is dependent on their parents (2014:67), and for this reason, the autonomy of children cannot be said to be violated by their parents through the use of biotechnology in any greater degree than already happens naturally.

It might therefore be convincingly argued that the utilisation of GE does not necessarily mean that autonomy has to be threatened. While some points of criticism are addressed admirably by the advocates of biotechnology, such as Habermas's notion of being the author of our own life, others remain in balance, such as the other concept he raises, namely viewing all people of being of equal worth. I will return to this idea shortly. It is still not clear, however, how one might respond to this issue from a theological perspective. Before I turn to the political theology of Jürgen Moltmann for guidance on this matter, it is important to take note that the defence of biotechnology on the grounds of personal liberty and that it does not undermine the autonomy of either the individual being altered or the values of the liberal state is essentially an extremely individualistic argument and one that does not take the interrelationship between people into account. Making our children healthier or smarter, or giving them more talents and self-control also means that there are others who do not have access to the biotechnology to do the same for their children or to put it even more bluntly, cannot afford to ${ }^{2}$.

In formulating his theory of libertarianism, Nozick also argued that it might be necessary to restrict the liberty of some in order to enhance the liberty of others (1974). This type of argumentation, one that also takes equality

2 See Kotzé, M 2014. Human Genetic Engineering in the South African Context with its Inequalities: A Discourse on Human Rights and Human Dignity. Scriptura, 113. 
and equal opportunity, two other important features of liberal democracy, into account, is sorely lacking from this kind of defence. One aspect that comes to the fore very strongly in the discussion on autonomy, as has also been mentioned earlier, is the notion of liberty. Wheeler postulates that reproductive autonomy is primarily a negative right, the right to remain free from any intrusion or intervention, rather than a positive right such as a claim to help (2003:242). In the next section, this notion of freedom in terms of reproductive autonomy will be briefly discussed, before turning to a possible theological response.

\section{Liberal democracy and parental liberty}

In her discussion of reproductive autonomy, Wheeler also differentiates between liberty as the freedom from all forms of interference, the liberty espoused by liberal democracy, and parental liberty, which does not focus on the freedom of a single individual, but rather "on the significance of a certain, crucial relationship whose importance to individuals and to social groups is hard to overstate" (2003:243). The scope of parents' influence and concern over the lives of their children and as a result also over the wider society is immense.

For that reason, parental freedom is protected, as parents should not only nurture and protect their children, but also provide them with value structures and a consistent worldview, parental liberty is not arbitrary, but directed towards an end; "to foster, facilitate, and protect the vital role of the parent, directly for the sake of the child who is to be cared for, and indirectly and secondarily for the sake of the wider society into which the child will enter when grown" (Wheeler 2003:244). In short, Wheeler therefore argues that while personal and individual freedom and the freedom from any and all interference seem to be the focus in liberal democracy, there are also some restrictions to this liberty. To a certain degree, parental liberty in intervene and even override the freedom of their children are allowed and encouraged when it is for the betterment of the child and, accordingly, for the rest of the society that child will become part of. On this basis, one could say that the genetic intervention, when done for the enhancement of the child in question, should also be left to the parents' discretion as part of the social protected parental liberty. 
Referring directly to the alteration of genetic makeup, Wheeler argues that parental liberty is accepted and protected because its focus is on the wellbeing of children, as well as the wider society indirectly, it follows that "any proposed intervention must pass the tests of being undertaken directly and primarily for the sake of the child rather than the parents of other parties" (2003:248). There is therefore a distinct difference between modifying the genetic composition of a future child in order to prevent a genetic disease than would cause considerable suffering to the child, and simply selecting traits that the parents subjectively view as being more socially desirable.

Wheeler sees liberty as more than just individual freedom, an aspect that is also located in the work of Jürgen Moltmann, who in his newer publications also explicitly refer to the issue of genetic engineering, indicating that alterations that aim to cure and heal are "of course ... permissible" (1999:126). In Wheeler's words, modifications that focus on the wellbeing of the child and, to a lesser extent, society, and not the preferences parents might have. This is also evident in his theology. In the last section, I now turn to Moltmann's theology as a theological response to the notions of liberty and autonomy in liberal democracy. Moltmann is a relevant and appropriate theologian to offer guidance in this regard, given that not only has he recently offered explicit statements on the issue of genetic engineering, but also given that notions such as freedom and autonomy are central to his theology. Additionally, Moltmann has engaged with the public sphere since the publication of his first book, Theology of Hope, and has presented a public theology that does not function in isolation, but engages with society, polity, structures, organizations and civil society.

\section{A theological response: Jürgen Moltmann on human dignity and Christian freedom}

Through his many books, Jürgen Moltmann constantly offers an impassioned appeal for the church to engage with the world by calling the world to justice, liberation, and environmental stewardship. To accomplish this aim, he has been a staunch advocate for Christian engagement also with political structures. 
For Moltmann, political theology is not theology about the political, but the analysing and reconstructing of theology as a whole in light of its political functions, designating the field in which Christian theology should be articulated, but the content is not derived from the situation (Rasmussen 1995:47).

Moltmann indicates that political theology is not a new dogma, but rather theology that is aware of its political function. In his opinion, a-political theology does not exist, only theology that is politically naïve, so to speak (1984:153).

Two notions are of special importance in the response to the concepts of autonomy and liberty as found in liberal democracy and in this section, I discuss Moltmann's view on human dignity and Christian freedom, before a theological response to the challenges posed by GE will be formulated in the conclusion.

\subsection{Human dignity}

Human dignity is one of the most important guiding principles in Moltmann's theology.

Willem Fourie also indicates that human dignity is inherently bound up to the Protestant principles identified by Heinrich Bedford-Strohm, Traugott Jähnichen, Sigrid Reihs, Hans-Richard Reuter, and Gerhard Wegner for a Christian social ethics, a subdivision of Christian ethics interested in institutions, systems and processes. Protestant social ethics ensues from the Reformation's core principle, namely, that God has granted every human being inalienable dignity. This is also then the first principle identified in Bedford-Strohm et al's principles for a Protestant social ethics. The second principle is that this dignity enables human beings to participate in God's reality in love, to also serve others. The third principle denotes that people should discover their own gifts and capabilities in the realisation of this dignity. These three principles lead to the remaining principles, the vision of society in the social ethical perspective. For this reason, the fourth principle indicates that for a society to be described as just, it should operate in a manner that the dignity of human beings is respected and the freedom of the individual is increased by the operation of the state, economy, science and civil society. The fifth principle affirms that this 
dignity and freedom in a space where people are able to realise their calling, caring for themselves and others. This principle is also dependent on the realisation of the sixth principle, which states that justice is the enabling of equal opportunities to all people. The seventh principle indicates that the unequal distribution of wealth and property can only be tolerated when it is to the benefit of the least well-off member of society ${ }^{3}$, while the eighth principle condemns any system of distribution that harm the dignity and freedom of people to serve others as part of their calling and that creates system that value wealth and property as ends in themselves. The ninth principle reiterates the importance of freedom, solidarity and justice in a social market economy. Principles seven, eight and nine are all linked to just systems of wealth distribution, while the last principle pronounces the potential that social ethics holds to contribute to the development of human systems, institutions and societal processes (2013:2-4).

Quite obviously, this is an extremely relevant system of principles to use in the discussion on political theology and liberal democracy.

These principles are then not compatible with the highly individualistic notions of autonomy and liberty than advocates of GE appeal to. While it might be argued that the discovering of talents and gifts being the realisation of dignity and that these endowments might enable one to also serve others, none of the supporters of biotechnology cite this as their reasons. The notions of inequality and distributive justice that these principles highlight are also not responded to by advocates like Blackford and Bostrom.

Human dignity is both the root of human rights and the bond unifying different categories of rights, be it protective rights, the rights to freedom, social rights or rights of participation (Moltmann 1999:119). Moltmann further clarifies that human dignity is not the elevation of human beings above other living things and cannot be upheld at the expense of nature (1999:120). Individual and social rights also belong together and

3 This is also one of the principles identified by John Rawls in his theory of social justice articulated in his A Theory of Justice (1971).

4 See also Moltmann (2011:611) and Bauckham (1995:17). 
one cannot take precedence over the other (Moltmann 1999:123-124). Moltmann explains it in the following way:

The fact that all human beings are made in the image of God is the foundation of human dignity. Human beings are intended to live in this relation to God. That gives their existence its inalienable, transcendent depth dimension. In their relationship to the transcendent God, human beings become persons whose dignity must not be infringed. (Moltmann 1999:122)

Moltmann further describes human beings as made in the image of God as pertaining to the human being "in allen seinen Lebensbezügen" (1984:169), in other words, the economic, social, political and personal dimensions are meant to reflect the confession that we are created in God's image.

Human dignity, Moltmann states, is already defined in the Old Testament: "The Abrahamic religions - Judaism, Christianity and Islam - are responsible for the religious background of Western civilizations, and they have always seen this dignity as belonging to the human being as the image of God" (2012:87). ${ }^{6}$ For a long time, this dignity was viewed as something that resided in the human soul, not in the body, and through this perspective the body came to be viewed as something that does not form part of the likeness to God and that the soul could simply make use of. Still later, the likeness to God came to be seen as "the conscious subjectivity of will and perception" (Moltmann 2012:87). However, as Moltmann is quick to point out, it is the whole of the human being that is the image of God, his or her body included (2012:87). For the discussion of human dignity within the sphere of the larger Christian bioethical debate on GE, the implications of this affirmation are that human dignity also refers to bodily dignity.

This also further means that human dignity should apply equally to all human beings, solely on the basis of their being human, and picks up on one of the points of criticism raised earlier by Habermas, namely that autonomy is violated in that altered individuals might not be able to view all people as being born equal and with equal worth.

5 See also Moltmann (1984:170-172; 1993c:181).

6 See also Moltmann (2012a:87-88). 
Another important notion in Moltmann's theology that has a direct impact on the notion of biotechnology in the discussion of liberal democracy is freedom, given that the idea of liberty, and especially personal liberty, plays such an important role in the arguments in favour of GE.

\subsection{Freedom}

In Church Dogmatics I/II section 28, Karl Barth, in an attempt to mediate between the concepts of liberty and God's goodness, defined God as "the One who loves in freedom". He continually relates God's freedom to God's love. Moltmann, however, sees various ambiguities in this, stating:

...either God loves as one who is free, who could just as well not love; or his freedom is not distinguished from his love at all, and he is free as the One who loves. In the first case there is still an arbitrary element, which makes responding love difficult. In the second case there is a tautology. (1993a:55)

For this reason, Moltmann then chooses the concept of freedom belonging to the language of community and fellowship; mutual participation in life, communication without lordship or servitude, becoming free beyond the limitations of individuality. "God demonstrates his eternal freedom through his suffering and his sacrifice, through his self-giving and his patience", whereby God keeps humanity, God's image and God's world, God's creation, free and pays the price for our freedom (1993a:56).

The notion of liberty in Moltmann's theology is thus radically different from the liberty advocated by Robert Nozick, who understood is as the freedom to act in any way that a person might choose, not restricted in any way by others; the highest level of individualism. Although Nozick did also concede that the freedom of some might have to be restricted in order to benefit the freedom of others, his theory remains staunchly individualistic and one that does not take the interrelationship between human beings into account, even less so the interrelationship between human beings and the earth.

From this individualistic perspective, the utilisation of biotechnology such as GE can indeed be incorporated in making sure that our children are better off than others, and focusing only on ourselves and our children; their future, their talents, their health... It is, however, not compatible with 
the idea of Christian freedom in community and relationship with God and others that Moltmann develops, at least not without also taking social inequality and distributive justice into account. One could develop an entire argument focusing only on this matter of social justice, which I have also recently done. In this article, however, I only mention it in relation to the arguments on autonomy and freedom.

\section{Conclusion}

Moltmann indicates "Christian identification with the crucified Christ means solidarity with the sufferings of the poor and the misery both of the oppressed and the oppressors" (1993b:25). For the Christian ethical discussion on GE, this would mean that human dignity, as humanity created imago Dei must be respected, and that this dignity should not infringe on the created dignity of nature and other living things. Respecting human dignity could be interpreted in some circles as respecting the human genome as it exists in nature and that any interference would be a violation of the human dignity of the individual involved. Together with Moltmann, however, I disagree with this type of discourse and instead deem it a breach of the human dignity of the affected individual when the technology exists that is able to repair genetic defects or heal a crippling hereditary disease. Respecting the human dignity of that individual, which includes the right to a life of dignity, may very well rather mean offering him or her every chance at a life of dignity, even when that should be materialised through biotechnological intervention. It is unclear why healing hereditary ailments and genetic defects would threaten the notion of human dignity. What reasonable person would not want the inherent human right to dignity exercised on their behalf, when the alternative is lifelong suffering from the affliction of a genetic disorder that would otherwise have been preventable?

In arguing that the concept of human beings created in the image of God does not have to rule out all forms of GE, I would like to emphasise the difference between healing and enhancement. ${ }^{7}$ In claiming that GE can be

7 I concede that this is a very difficult distinction to make and one that had been subject to much debate. I use healing though GE here to refer only to the genetic alteration that prevents genetic disorder from materialising. 
utilised and sanctioned as compatible with the Christian view of human beings created imago Dei, it is the utilisation of these types of technology for the purposes of curing hereditary diseases and repair genetic defects that is being referred to. As previously indicated, Moltmann also explicitly states:

Of course therapeutic interventions are permissible if their aim is to heal. But manipulations designed to breed living things lacking in the human quality of 'subjecthood', and manipulations the purpose of which is to breed so-called supermen, destroy the essential nature of human beings, and hence the dignity of humanity too. (1999:126)

Moltmann affirms that the first step into the realm of freedom is the mastery of nature through science and technology, given that the distinct history of humanity with nature begins with the progressive freedom of human beings from their dependency on nature and their progressive selfdetermination. The attaining of power, however, is not yet the determination of how that power will be utilised (1993a:213).

The ethos of learning to live with brokenness, imperfection and vulnerability that Moltmann propagates, also be referring to the suffering of and vulnerability of God, is of immense value to the discourse of GE. Moltmann especially referred to the reality that God is seen most clearly in God's broken and vulnerable humanity. In his understanding the whole of creation through the event of the cross, this also becomes especially applicable. Moltmann's trinitarian doctrine of creation helps the Christian bioethical discussion on GE in explicitly campaigning for the utilisation of available biotechnologies to heal and cure, thereby enhancing human dignity and equal opportunity as part also of the human rights discourse. In addition, Moltmann's theology also helps Christian bio-ethical discourse by resisting a culture or ethos that cannot live with vulnerability. Moltmann looks at creation and human beings through the lens of God who suffers in and through Jesus Christ. Although I derive from his theology a theological mandate in favour of GE, I by no means infer from him a flight from vulnerability, brokenness and suffering that aims to become 'transhuman'. I do not infer from his position an idealisation and even idolisation of medical technology. His theological perspectives do indeed encourage us to support medical, scientific and technological progress. It 
supports the quest for health and health care, but also acknowledges the limitations in the best that we can achieve as human beings.

Moltmann's public theological, human dignity and Christian freedom focus helps us to address bio-ethical challenges in the context of inequality, especially in a country like South Africa and helps us to build a life of dignity also for the socio-eluded ones in society and therefore, to work for socio-economic conditions that make this technology accessible to all.

\section{Bibliography}

Annas, GJ 2005. American Bioethics: Crossing Human Rights and Health Law Boundaries. Oxford: Oxford University Press.

Bauckham, R 1995. The Theology of Jürgen Moltmann. London: T\&T Clark.

Blackford, R 2014. Humanity Enhanced: Genetic Choice and the Challenge for Liberal Democracies. Cambridge: The MIT Press.

Bolstrom, N 2005. "In Defence of Posthuman Dignity", Bioethics 19, pp. 202-214.

Fourie, W 2013. "Social ethics in South Africa: Initiating a dialogue between its relevance and current status," HTS Teologiese Studies/ Theological Studies 69(1), Art. \# 1978, 9 pages. doi: 10.4102/hts. v69i1.1978.

Fukuyama, F 2002. Our Posthuman Future: Consequences of the Biotechnology Revolution. London: Profile Books.

Gavaghan, C 2007. Defending the Genetic Supermarket: The Laws and Ethics of Selecting the Next Generation. London: RoutledgeCavendish.

Lombard, C 2011. "Church, God, and Civil Society: A Namibian Case Study," in A World for All? Global Civil Society in Political Theory and Trinitarian Theology, WF Storrar, PJ Casarella \& PL Metzger eds., Grand Rapids: William B Eerdmans.

Moltmann, J 2012. Ethics of Hope, Minneapolis: Fortress Press. 
Moltmann, J 2011. "On a culture of life in the dangers of this time," in Living Theology: Essays presented to Dirk J Smit on his sixtieth birthday, L Hansen, N Koopman \& R Vosloo eds., Wellington: Bybelmedia, pp 607-613

Moltmann, J 1999. God for a Secular Society: The Public Relevance of Theology, Minneapolis: Fortress Press.

Moltmann, J 1993a. The Trinity and the Kingdom, Minneapolis: Fortress Press.

Moltmann, J 1993b. The Crucified God, Minneapolis: Fortress Press.

Moltmann, J 1993c. The Church in the Power of the Spirit, Minneapolis: Fortress Press.

Moltmann, J 1984. Politische Theologie - Politische Ethik, Munich: Kaiser Press.

Nozick, R 1974. Anarchy, State and Utopia. New York: Basic Books.

Rasmussen, A 1995. The Church as Polis: From Political Theology to Theological Politics as Exemplified by Jürgen Moltmann and Stanley Hauerwas. Notre Dame, Indiana: University of Notre Dame Press.

Sandel, M 2007. The Case against Perfection: Ethics in the Age of Genetic Engineering. Cambridge: Belknap Press.

Shaw, W 2005. Business Ethics. Belmont: Thompson/Wadsworth.

Somerville, M 2007. The Ethical Imagination: Journeys of the Human Spirit. New York: Viking Press.

Wheeler, S 2003. "Parental Liberty and the Right of Access to GermLine Intervention: A Theological Appraisal of Parental Power", in Designing our Descendants: The promises and perils of genetic modifications, AR Chapman \& MS Frankel, eds Baltimore: The Johns Hopkins University Press. 